\title{
Severe disability: Do primary health care nurses have a role to play?
}

\author{
J Bornman, Ph D, Centre for Augmentative and Alternative Communication, (CAAC), \\ University of Pretoria \\ E Alant, Ph D, Centre for Augmentative and Alternative Communication (CAAC) \\ University of Pretoria \\ LL Lloyd, Ph D, Educational Studies (Special Education), Purdue University, West \\ Lafayette, Indiana, USA
}

\section{Abstract}

This article focuses on the importance of primary health care nurses' involvement in the identification of children with severe disabilities, early and appropriate intervention that includes referral, as well as the provision of support to the children's caregivers. The use of multiskilling as a strategy to train nurses to fulfil this role is described. The traditional roles of community nurses are explored within the disability paradigm, with specific reference to multi-skilling. Finally, research results following the implementation of the Beginning Communication Intervention Protocol (BCIP), which uses multiskilling as a training strategy, are described. Recommendations for further research are then provided.

\section{Opsomming}

Hierdie artikel fokus op die belangrikheid van gemeenskapsverpleegkundiges se betrokkenheid by die identifikasie, vroeë en toepaslike verwysing en intervensie van kinders met erge gestremdheid en die ondersteuning van hulle versorgers. Die gebruik van veelvuldige vaardighede as " $n$ strategie om verpleegkundiges op te lei om hierdie rol te vervul word bespreek. Die tradisionele rolle van gemeenskapsverpleegkundiges word in die gestremdheidsparadigma ondersoek, met spesifieke verwysing na veelvuldige vaardighede. Ten slotte word navorsingsbevindinge bespreek na die implementering van die Beginnende Kommunikasie Intervensie Protokol (BKIP), wat veelvuldige vaardighede as opleidingsstrategie gebruik. Aanbevelings vir verdere navorsing word dan verskaf.

\section{Introduction}

In an earlier article Alant (1998:20) stressed the need for primary health care nurses to become more involved in the identification of and intervention with children with severe disabilities (CSDs), in particular those who have little or no functional speech. This need for nursing intervention is based on the fact that the incidence of non-speech is noticeably higher in South African schools for children with intellectual impairments than in schools reflected in comparable studies from other countries. For example, the South African figure was 38\% (Bornman \& Alant, 1997:17) as opposed to comparable data from North Dakota, USA which reported a rate of $2,4 \%$ (Burd, Hammes, Bornhoeft \& Fisher, 1988:371) and in rural areas of Washington State, USA where $6 \%$ was reported (Matas, Mathy-Laikko, Beukelman \& Legresley, 1985:20). There are a number of reasons for this high incidence. One of the most prominent is the lack of appropriate rehabilitation due to the limited number of trained professionals (e.g. therapists, teachers, nurses) in this field. In addition, services are often inaccessible as the majority of them are located in a few large cities, and transport difficulties in rural areas are notorious.

Despite this bleak picture, community health clinics that should render comprehensive integrated primary health care (PHC) services using a one-stop approach, are accessible to the majority of South Africans (Department of Health, 1999:13). Primary health care nurses are often the first professionals who come into contact with children with severe disabilities and their caregivers and/or parents (Clark, 1996:61). With the move towards the inclusion of people with severe disabilities, the majority of these individuals live with their parents (or extended families) and thus need to adapt to community living, making it mandatory that their needs be viewed within the context of the family and the community (National Department of Education, 2002:20).

Primary health care nurses are often the only professionals who provide continual support and assistance to these 


\section{Figure 1 : Roles of primary health care nurses within multi-skilling levels}

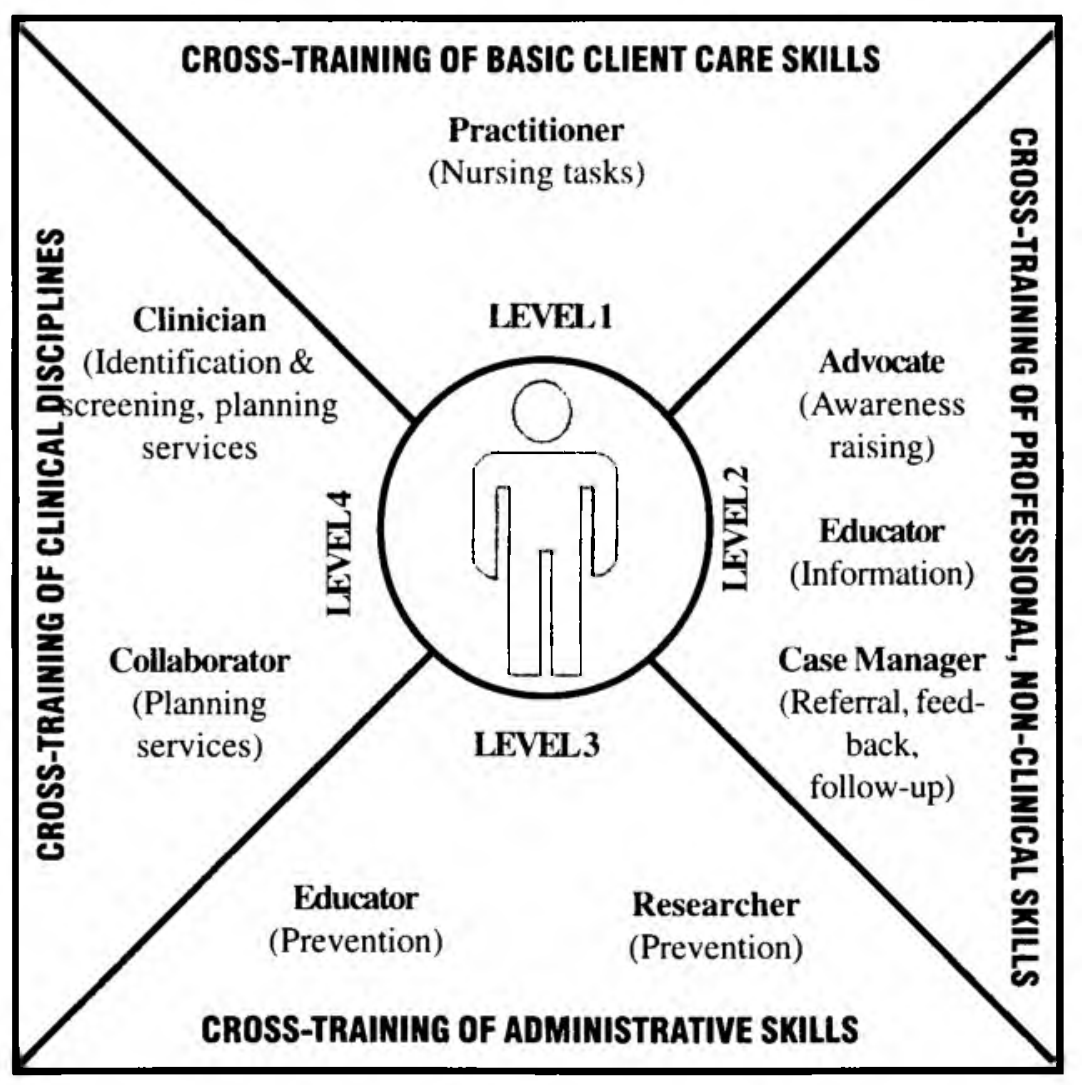

individuals and their caregivers, because nurses are readily accessible and often act as the bridge between other professionals and the caregivers. Furthermore, as nurses are trained in active listening, caregivers perceive them as approachable and concerned advisors who can identify with the problems that concern the family, and who will help the family achieve their best possible health condition (Hitchcock, 1999:426). In view of the shortage of qualified health care professionals in South Africa (Bortz, Jardine \& Tshule, 1996:467), primary health care nurses are ideally positioned to provide services to caregivers of CSDs (Moodley, Louw \& Hugo, 2000:26). They are equipped to perform this task because their training provides them with the skills to observe behavioural patterns and environmental concerns, which enables them to make recommendations where necessary. It is therefore clear that primary health care nurses need to be equipped with the necessary knowledge and skills to function as part of a health care team when assisting caregivers in dealing with their CSD's.

One way in which primary health care nurses can be equipped to do this, is though multi-skilling. Multi-skilled health professionals can be defined as persons crosstrained to provide more than one function, often in more than one discipline. These combined functions can be found in a broad spectrum of health-related jobs, ranging in complexity from the non-professional to the professional level, including both clinical and management functions. Traditional functions ( skills) added to the original health care worker's job may be of a higher, lower or parallel level (American Speech and Hearing Association, 1996:54).

These specific nursing tasks and roles at each multi-skilling level, as well their application to disability, are depicted in Figure 1 (American Speech and Hearing Association 1996:56, Hurst, 1999:170; Pietranton \& Lynch, 1995:38, South African Nursing Council, 1985:3; South African Nursing Council, 1984:2; Wilkey \& Gardner, 1999:303).

All primary health care nurses have the role of nursing practitioner. Community health nursing includes both personal health (focused on the individual and mostly including the maintenance of health and recovery from illness) and public health (promoting and protecting the health of the community) (Thomas, 1999:17). These domains relate to the first level of multi-skilling, namely cross-training in basic patient care skills. Because the activities at this level mostly refer to traditional nursing tasks covered by the basic nursing curriculum (South African Nursing Council, 1985:2), they will not be further discussed.

At the second multi-skilling level, the primary health care nurse has three major nursing roles: providing effective patient advocacy, executing education programmes and co-ordinating the health care regimens provided for the individual (South African Nursing Council, 1984:1). The advocate role requires the primary health care nurse to speak or act on behalf of individuals who may be unable to speak for themselves (e.g. CSDs and their caregivers) as a result of limited knowledge; difficulty or inability in articulating their own needs or ideas; fear; perceived lack of power; and/or intellectual or physical disability (Wilkey \& Gardner, 1999:306). Advocacy also entails the preparation of individuals to stand alone and to speak for themselves rather than remaining dependent on the nurse (e.g. by introducing them to disabled people's organisations) (Clark, 1996:64). As a result of their close contact with CSDs and their caregivers, nurses are often the best health professionals to promote the needs and desires of these children. One of the major nursing tasks would be raising awareness about disability issues in the community; for example, by giving health talks.

Linked closely to the advocate role is that of educator. Health teaching and the provision of information are viewed as essential nursing responsibilities. Education can be conducted at the individual level (assisting CSDs and caregivers to make informed decisions about rehabilitation) or at a community level (e.g. health talks about disability) (Wilkey \& Gardner, 1999:309).

Thirdly, the nurses act as co-ordinators or case managers of the health care regimens at the second level of multi- 
skilling. This role implies the application of strategies to co-ordinate and allocate services for individuals who cannot manage their own care (e.g. CSDs and their disempowered caregivers) (Lerner \& Ross, 1991:47; Wilkey \& Gardner, 1999:312). The primary nursing tasks as applied to CSDs, and their caregivers would entail identification of CSDs and referral when needed. These tasks highlight the importance of feedback and follow-up in the attempt to monitor a child's progress. Primary health care nurses should be sensitive to the needs and circumstances of the caregivers, because they may appear to be non-compliant (e.g. may not attend referral and/or not return for feedback and follow-up) if they do not share the professional's values and priorities. This failure in turn leads the nurse to experience frustration and hostility (Humphry, 1995:692).

At the third multi-skilling level, primary health care nurses act primarily as educators and researchers. The importance of education has already been highlighted. At the third level, education is specifically related to the prevention of disability (at primary, secondary and tertiary levels). Enhancing this preventative function evinces an enquiring and scientific approach requiring primary health care nurses to also act as researcher (South African Nursing Council, 1985:3; Wilkey \& Gardner, 1999:310). This may include tasks such as identifying problem areas; collecting, analysing and interpreting data; applying findings; and evaluating, designing and conducting research (Griffith, 1994:69; Wilkey \& Gardner, 1999:310). This thinking requires sensitivity towards evidence-based practice.

Finally, at the fourth multi-skilling level, the nurses have two main functions - those of clinician and of collaborator. The role of clinician at this level is broader than on the first level, because it also entails an intervention function, albeit limited. At this level of multi-skilling nurses act as collaborative professionals moving the strict traditional boundaries of their discipline to facilitate the planning of further services, namely identification, screening and planning of services for CSDs. Full case management itself would thus entail counselling on prevention, follow-up, providing medication, collaboration and referral (Wilkey \& Gardner, 1999:302). The collaborator role is closely linked to the provision of services, and also to other roles (e.g. advocate and educator). Consultancy requires that primary health care nurses help individuals to understand their disabilities and make informed decisions about their own rehabilitation (American Association of Colleges of Nursing, 1996:1 19; Wilkey \& Gardner, 1999:307).

When looking at the four multi-skilling levels, it is important to note that these skills cannot be viewed as distinct categories, and that extensive overlapping occurs. The levels are also dynamic in nature and may change over time, or according to the needs of the CSDs and their caregivers. These needs are in turn influenced by, among other factors, the specific disability type. However, in an attempt to clarify specific nursing tasks as they pertain to disability, these categorical distinctions were made. Questions also remain unanswered regarding the application of multiskilling within various health care settings (e.g. would multi- skilling be applied differently in primary, secondary and tertiary health care settings?), geographical areas (e.g. rural vs. urban), clinical disciplines and professions (e.g. nursing or speech and language pathology) (Pietranton \& Lynch, 1995:38) and national policies and frameworks (e.g. how will the National Qualification Framework that endorses learning and skills acquired through experience and in-service training, view multi-skilling?)(Geyer, 1997:11). Another grave concern about multi-skilling is that it might add to the workload of already over-burdened primary health care nurses. Professionals working in the health care arena are diverse regarding education, experience, training, autonomy and level of client contact, and therefore a unified approach to multi-skilling seems unlikely.

The current article will argue that primary health care nurses should be equipped, through multi-skilling, to function as part of a multi-disciplinary team, capable of delivering services to one of the most neglected groups of individuals in their clinics, viz. those with severe disabilities.

\section{Research results on multi- skilling}

The aim of the research was to train nurses in applying the Beginning Communication Intervention (BCIP) protocol aimed at equipping them with basic knowledge and skills related to service provision to CSD's and their caregivers. This protocol is aimed at multi-skilling levels 2, 3 and 4 (See figure 1). This research formed part of a PhD study; twenty primary health care nurses from the Moretele Health District (in the North West Province) were trained using multiskilling principles (Bornman, 2001:4-25). Research consisted of a pre-experimental and an experimental phase.

\section{Pre-experimental phase}

The first phase of the research was to conduct a needs analysis by means of focus group discussions (qualitative data) and a questionnaire (quantitative data) in order to (i) ascertain the perceptions of community nurses regarding service delivery to CSDs, (ii) determine nurses' exposure to CSDs, and (iii) establish how primary health care nurses perceived the needs of CSDs and their caregivers.

Results indicated that nurses did indeed feel that they had a role to play in providing services to this population, and that their current roles mostly included obtaining a case history, conducting a physical examination, detecting the problem, conducting health promotion (e.g. through health talks), treatment of minor medical ailments, referral and follow-up (Bornman, 2001:6-6). However, they also expressed feelings of inadequacy because they did not know how to handle the caregivers of CSDs, depression, attitudinal barriers (due to limited staff and time constraints) and the lack of follow-ups. In order to address feelings of inadequacy, the second phase of the research commenced.

\section{Experimental phase Aims}

The main aims of this phase were to describe the multi- 
information about the nurses is presented in table 1 .

\section{PHASE DESCRIPTION}

Phase $\mathbf{O}_{1} \quad$ Identifying skill dimensions: Skills, knowledge and attitudes of community nurses before training. Data obtained by means of response form I and II.

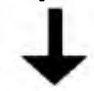

Phase $\mathbf{X}$ Training conımunity nurses in the application of the BCIP. A summary of the training is presented in Appendix I.

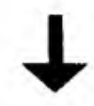

Phase $\mathrm{O}_{2}$ Skills, attitudes and knowledge of community nurses directly post-training. Data obtained by means of response form I and II.

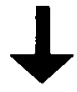

Phase $\mathrm{O}_{3} \quad$ Follow-up consultation 2 weeks post-training: Assessing skills of community nurses. Identification of problem areas and problem solving. Data obtained by means of response form $I$.

Phase $\mathrm{O}_{4} \quad$ Follow-up consultation 6 weeks post-training: Assessing skills of community nurses. Identification of problem areas and problem solving Data obtained by means of response form I.

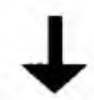

Phase $\mathbf{O}_{5} \quad$ Follow-up consultation 5 months post-training: Assessing skills, attitudes and knowledge of community nurses. Data obtained by means of response form I and II

\section{Instruments used}

In order to meet the requirements posed by the research question and design, two measuring instruments, response forms I and II, were developed, as well as the BCIP training procedure. They can briefly be described as follows:

\section{Response form I}

This structured interview dealt primarily with the skills and applied knowledge of the nurses and was based on a specific case study. A different, but comparable case study was used for each of the research phases in order to counteract familiarity. The four different case studies that were used are presented in Appendix II. Response form I consisted of five sections, namely the biographic data, the applied knowledge

skilling dimensions relevant to primary health care nurses when working with CSDs and to discuss the outcomes following training aimed at multi-skilling Level 2 (cross-training of professional non-clinical skills), Level 3 (cross-training of administrative skills) and Level 4 (cross-training of clinical disciplines).

\section{Research design and phases}

A quasi-experimental time series group design $\mathrm{O}_{1}-\mathrm{X}-\mathrm{O}_{2}-\mathrm{O}_{3}-$ $\mathrm{O}_{4}-\mathrm{O}_{5}$ with withdrawal was used as it was appropriate to determine knowledge and skills acquired over time (Brink, 1999: 105). These phases all followed a linear course and are presented in figure 2 .

\section{Participant selection and description}

Two selection criteria were used, namely that the nurses had to be employed by the Moretele Health District and that they had to be working in either a community health clinic or a mobile clinic. Non-probability sampling techniques were used to select participants. Firstly purposeful sampling was used as the assistant Director of Health in the particular area selected nurses who were eager to receive further training in this field. Secondly a convenience sample was used in order to least disrupt service delivery (e.g. nurses from the same clinic were not used, and neither were nurses who were on leave, close to retirement, on night duty, etc.). Although these sampling techniques had many advantages for the present research, it hampered generalisability of results (Brink, 1999:140). This resulted in the selection of 20 primary health care nurses. Descriptive about the current abilities of the particular case study, applied knowledge about recommendations, a practical skill demonstration in using the BCIP with the particular case and finally their exposure to the BCIP. An outline is presented in table 2.

Basic considerations had to be taken into account when conducting these structured interviews and completing response form I as they impacted on the reliability and validity of the data. This included the following:

- All interviewers received the same training before the commencement of the structured interviews and the completion of response form I. In addition, an external rater, (who also received training) viewed all the structured interviews, which had been videorecorded, independently and coded responses on response form $I$. The inter-rater agreement averaged 96\% across all measurements (Bornman, 2001:5-3).

- These structured interviews were conducted in English. Although this was not the nurses' mother tongue, it was seen during the focus groups conducted in the pre-experimental phase (Bornman \& Alant, 2002:35) that their spoken use of English was good. It was assumed that this would not impact on the quality of the answers.

- All interviewers had access to response form I (containing explicit guidelines) as well as their interviewer notes to ensure that the procedure remained consistent. Eight open-ended questions were used for this purpose, e.g. "If you were the nurse work 


\begin{tabular}{|c|c|c|c|c|}
\hline Description & Results & & & \\
\hline $\begin{array}{l}\text { The nurses' ages ranged from } 28 \text { to } 54 \text { years and they } \\
\text { tended to be older, with the majority being between } 41 \text { and } \\
45 \text { years of age. This highlights the fact that this is a group } \\
\text { of adult leamers and that adult teaching and learning styles } \\
\text { had to be taken into consideration with the BCIP training. }\end{array}$ & 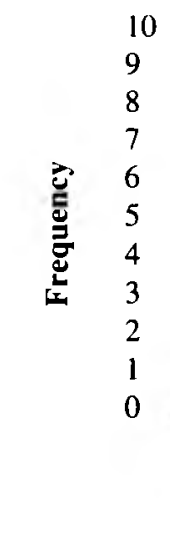 & 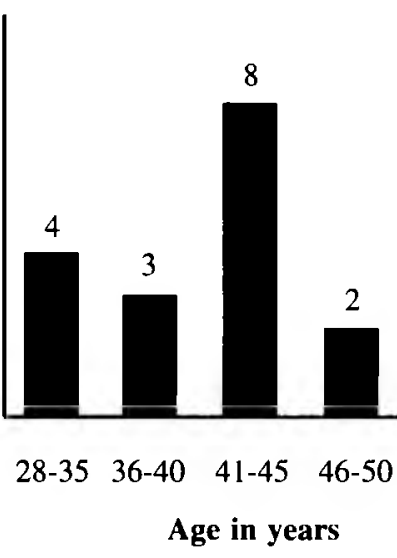 & $\left.\right|_{51-54} ^{3}$ & \\
\hline $\begin{array}{l}\text { Qualifications covered a broad spectrum, ranging from no } \\
\text { formal training after school (Grade } 8 \text { ) to being highly quali- } \\
\text { fied (a nursing degree). Eight of the nurses had no formal } \\
\text { training after leaving school while the majority had nurs- } \\
\text { ing diplomas (9). }\end{array}$ & 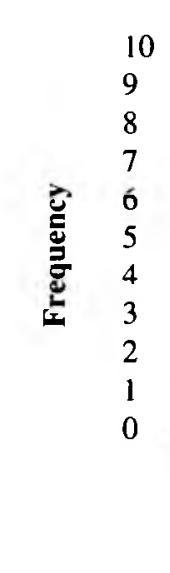 & 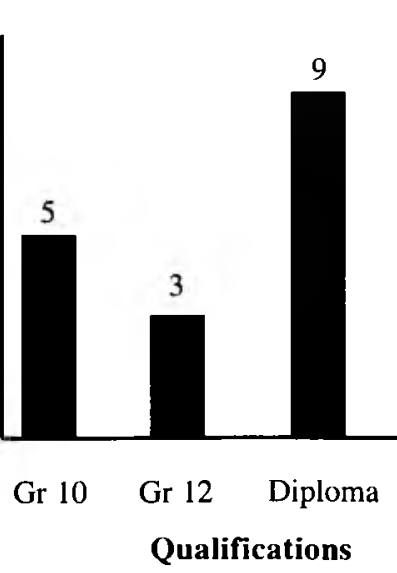 & Degree & \\
\hline $\begin{array}{l}\text { The majority were professional nurses (including senior } \\
\text { professional and chief professional nurses). No auxiliary } \\
\text { nurses were trained (nursing assistants) but three senior } \\
\text { auxiliary nurses were included. The four staff nurses are } \\
\text { receiving in-service training to equip them with the skills } \\
\text { to become professional nurses. }\end{array}$ & 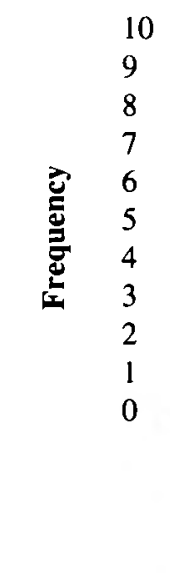 & \begin{tabular}{c|ccc}
3 & 4 & 4 \\
& & & \\
& & & \\
& & & \\
Snr & Staff $\quad$ Prof & $\begin{array}{c}\text { Snr } \\
\text { Pux }\end{array}$ \\
& Nursing Status
\end{tabular} & \begin{tabular}{|l} 
\\
\\
\\
\\
Chief \\
Prof
\end{tabular} & \\
\hline $\begin{array}{l}\text { Only five nurses had less than three years experience (in- } \\
\text { cluding one with less than a year's experience) while three } \\
\text { of them had more than } 20 \text { years experience. }\end{array}$ & 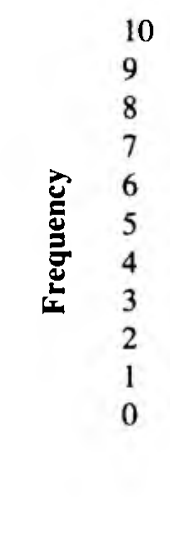 & 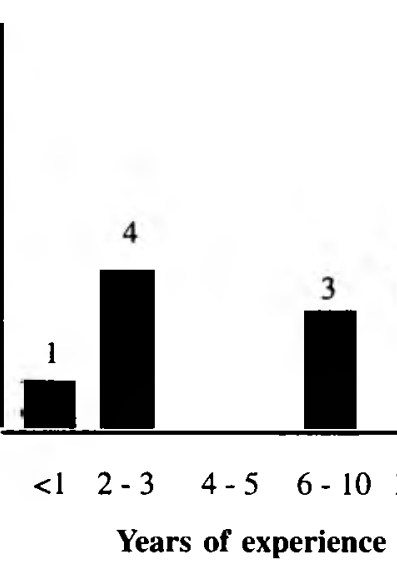 & $\frac{\mid}{1-15}$ & 2 \\
\hline
\end{tabular}




\begin{tabular}{|c|c|c|c|c|c|}
\hline $\begin{array}{l}\text { Se c - } \\
\text { tion }\end{array}$ & Category & $\begin{array}{l}\text { Question } \\
\#\end{array}$ & $\begin{array}{l}\text { Total \# of } \\
\text { questions }\end{array}$ & Question area & Type of question \\
\hline A & Biographic data & 1 & 1 & 1. Birth date & Open-ended question \\
\hline B & $\begin{array}{l}\text { Applied knowl- } \\
\text { edge about current } \\
\text { abilities of case } \\
\text { study }\end{array}$ & $\begin{array}{l}1.1 \\
1.2 \\
1.3\end{array}$ & 3 & $\begin{array}{l}\text { 1. Communication means } \\
2 \text {. Communication func- } \\
\text { tion } \\
\text { 3. Communication part- } \\
\text { ners }\end{array}$ & $\begin{array}{l}\text { Open-ended question that are } \\
\text { stored in matrix format allowing } \\
\text { for a "other" category }\end{array}$ \\
\hline $\mathrm{C}$ & $\begin{array}{l}\text { Applied knowl- } \\
\text { edge about recom- } \\
\text { mendations (ad- } \\
\text { vice) }\end{array}$ & $\begin{array}{l}2.1 \\
2.2 \\
2.3 \\
2.4 \\
2.5\end{array}$ & 5 & $\begin{array}{l}\text { 1. General advice } \\
\text { 2. Communication means } \\
\text { 3. Communication func- } \\
\text { tion } \\
\text { 4. Communication oppor- } \\
\text { tunities } \\
\text { 5. Communication part- } \\
\text { ners }\end{array}$ & $\begin{array}{l}5 \text { Open-ended questions that are } \\
\text { recorded verbatim on this ques- } \\
\text { tionnaire }\end{array}$ \\
\hline D & Skill demonstration & $\begin{array}{l}3.1 \\
3.2 \\
3.2\end{array}$ & 3 & $\begin{array}{l}\text { 1. Practical skills demon- } \\
\text { stration } \\
\text { 2. Amount of prompting } \\
\text { required } \\
\text { 3. Confidence in using } \\
\text { the BCIP }\end{array}$ & $\begin{array}{l}\text { Question } 3.1 \text { was scored on a } 4 \text { - } \\
\text { point Likert scale whilst } 3.2 \text { and } \\
3.3 \text { were scored on a } 3 \text {-point } \\
\text { Likert scale }\end{array}$ \\
\hline $\mathrm{E}$ & Exposure & $\begin{array}{l}4.1 \\
4.2\end{array}$ & 2 & $\begin{array}{l}\text { 1. Utilising the BCIP with } \\
\text { patients } \\
\text { 2. Contact with col- } \\
\text { leagues about the BCIP }\end{array}$ & $\begin{array}{l}\text { Two Yes/No questions followed } \\
\text { by an open-ended question }\end{array}$ \\
\hline
\end{tabular}

ing with Sibusiso and Mrs Serudu, what advice would you give her?"

- Due to the specific research design (involving a preexperimental phase) rapport had already been established, and participants were aware of the aim of the research and were familiar with the researcher. The time series nature of the experimental phase of the research ensured that this rapport was maintained.

\section{Response form II}

This questionnaire had a total of 17 questions and five categories (biographic information, prior knowledge about disability and communication, attitudes and values, other positive outcomes and self-evaluation). Table 3 provides a summary of the most important areas covered.

Where possible, structured, close-ended questions were used. This format was selected to accommodate time constraints. Providing participants with a choice of possibilities from which they had to select one, acted as a prompt and enabled the researcher to obtain an idea of what they knew, not merely of what they were able to write and spell. During the pre-experimental phase it was seen that nurses feared to make spelling and grammatical errors. This type of format is also more motivational as it is easier and quicker to complete (McMillan \& Schumacher, 2001:261). In addition, answers were easily scored and analysed according to pre-assigned codes.

The disadvantages of close-ended questions are that they are more difficult to construct and the fact that relevant answers can easily be overlooked (McMillan \& Schumacher, $2001: 261$ ). In this research care was taken when reviewing the literature to determine possible answers; a pre-experimental phase was conducted (involving a focus group to highlight aspects that might not have been well described in the literature) and finally the questions were tested by means of a pilot study.

Some questions, e.g. Question 15 "When you think of your skills as a nurse, which three things do you do best?" was asked in open-ended format, so that the participants were not guided in a direction, and also to allow them to answer in their own words. To a small extent, these questions were also used in an attempt to countercheck some of the other questions and to control bias in the development of the questionnaire (Brink, 1999:155). 


\section{Table 3 Development of response form II}

\begin{tabular}{|c|c|c|c|c|c|}
\hline Section & Category & $\begin{array}{l}\text { Ques- } \\
\text { tion \# }\end{array}$ & $\begin{array}{l}\text { Total \# of } \\
\text { questions }\end{array}$ & Question area & Type of question \\
\hline $\bar{A}$ & $\begin{array}{l}\text { Biographic } \\
\text { data }\end{array}$ & $\begin{array}{l}1 \\
2 \\
3 \\
4 \\
5 \\
6\end{array}$ & 6 & $\begin{array}{l}\text { 1. Birth date } \\
\text { 2. Close relative with a disability } \\
\text { 3. Qualification } \\
\text { 4. Nursing category } \\
\text { 5. Experience at health clinic(s) } \\
\text { 6. Training in disability }\end{array}$ & $\begin{array}{l}\text { One open-ended ques- } \\
\text { tion, } \\
\text { Two Yes/No questions } \\
\text { (specify if "yes") } \\
\text { Three close-ended ques- } \\
\text { tions with "other" cat- } \\
\text { egory. }\end{array}$ \\
\hline B & $\begin{array}{l}\text { Prior knowledge } \\
\text { about disability } \\
\text { and communi- } \\
\text { cation }\end{array}$ & $\begin{array}{l}7 \\
8 \\
9\end{array}$ & $\begin{array}{l}\text { Three ques- } \\
\text { tions that } \\
\text { include } \\
23 \text { items }\end{array}$ & $\begin{array}{l}\text { 1. Knowledge about AAC } \\
\text { 2. Knowledge about severe } \\
\text { disability } \\
\text { 3. Communication modes, } \\
\text { functions, partners and } \\
\text { temptations }\end{array}$ & $\begin{array}{l}\text { One structured close- } \\
\text { ended question using } \\
\text { true-false-uncertian } \\
\text { format. } \\
\text { Two close-ended ques- } \\
\text { tions where answers are } \\
\text { plotted on a matric for } \\
\text { one and graded in terms } \\
\text { of difficulty for the other. }\end{array}$ \\
\hline C & $\begin{array}{l}\text { Attitudes and } \\
\text { values }\end{array}$ & & & & $\begin{array}{l}\text { Not relevant for the pur- } \\
\text { purpose of this article. }\end{array}$ \\
\hline D & $\begin{array}{l}\text { Other positive } \\
\text { outcomes }\end{array}$ & $\begin{array}{l}11 \\
12 \\
13\end{array}$ & 3 & $\begin{array}{l}\text { 1. Number of CSDs seen } \\
\text { 2. Amount of time spent } \\
\text { with CSD and caregiver } \\
\text { 3. Type of service delivery } \\
\text { provided }\end{array}$ & $\begin{array}{l}\text { Three close-ended ques- } \\
\text { tions. }\end{array}$ \\
\hline$E$ & Reflexive self- & $\begin{array}{l}14 \\
15 \\
16 \\
17\end{array}$ & $\begin{array}{l}\text { Four ques- } \\
\text { tions and } \\
\text { question } \\
14 \text { has six } \\
\text { items }\end{array}$ & $\begin{array}{l}\text { 1. Comfortable-ness in } \\
\text { handling disability } \\
\text { 2. Effectiveness } \\
\text { 3. Enjoyment } \\
\text { 4. Opportunity for service } \\
\text { delivery to CSDs } \\
\text { 5. Case management } \\
\text { (rapport and empathy) } \\
\text { 6. Self-evaluation of skills }\end{array}$ & $\begin{array}{l}\text { Three open-ended } \\
\text { questions and one } \\
\text { close-ended question } \\
\text { with } 6 \text { items using a } \\
\text { 4-point Likert scale. }\end{array}$ \\
\hline
\end{tabular}

A few general guidelines were taken into consideration with the development of questionnaires (Brink, 1999:156; McMillan \& Schumacher, 2001:258):

- Items were mostly short and care was taken to ensure that each question dealt with only one concept.

- Care was taken to avoid any biased or leading questions, jargon and other difficult terminology, and to ensure the clarity of the questions, so that all participants understood the same concepts with the vocabulary used.

- $\quad$ An attempt was made to keep the questionnaires as short as possible to ensure that participants did not lose interest and/or become fatigued resulting in the omission of any important information.
- Meticulous care was taken with the visual appearance of the questionnaires. Questions used during the different phases were printed on different coloured paper to make it visually more appealing. Questions were all numbered, organised in logical sequence and did not have too many items per page. Care was taken to ensure correct spelling and grammar throughout.

- Clear, brief instructions were included at the top of the questionnaires to guide the participants. They were encouraged to complete all questions as incomplete responses would impact on the reliability of the data.

\section{BCIP training procedure}

Training was conducted over five consecutive days, namely 


\section{Table 4 Nurses' self-evaluation of general nursing skills during the various research phases $(n=3 \times 20=60)$}

\begin{tabular}{|ll|l|l|c|}
\hline No Description & $\begin{array}{l}\text { Pre- } \\
\text { training } \\
\left(\mathbf{O}_{1}\right)\end{array}$ & $\begin{array}{l}\text { Post- } \\
\text { training } \\
\left(\mathbf{O}_{2}\right)\end{array}$ & $\begin{array}{l}\text { Post- } \\
\text { withdrawal } \\
\left(\mathbf{O}_{5}\right)\end{array}$ \\
\hline 1 & Case history and interviewing & 6 & 5 & 3 \\
\hline 2 & Communication and listening skills & 10 & 11 & 11 \\
\hline 3 & Providing correct medical (nursing) treatment & 10 & 7 & 11 \\
\hline 4 & Assessment & 6 & 8 & 6 \\
\hline 5 & Education through health talks & 13 & 9 & 10 \\
\hline 6 & $\begin{array}{l}\text { Counselling caregivers on accepting CSDs and adopting a positive } \\
\text { attitude towards them }\end{array}$ & 8 & 4 & 3 \\
\hline 7 & Home visits to support caregivers and CSDs & 2 & - & - \\
\hline 8 & Referrals & 5 & 4 & 5 \\
\hline 9 & Follow-up visits & - & 2 & 1 \\
\hline 10 & $\begin{array}{l}\text { Showing caregivers how to communicate by using different } \\
\text { communication means, functions, partners and opportunities }\end{array}$ & - & 9 & 10 \\
\hline 11 & Provide information regarding school placement & - & 1 & - \\
\hline & TOTAL & $\mathbf{6 0}$ & $\mathbf{6 0}$ \\
\hline
\end{tabular}

Please note that each of the 20 participants were requested to provide 3 answers, hence the total of 60 items.

Monday to Friday at the University of Pretoria's Hammanskraal campus in the Moretele district, as it restricted travelling time and costs for the nurses. Principles of adult learning were used throughout the training. Each day the training started with a brief revision of the previous day's work. The nature of the training was problem-based as it has repeatedly been shown that adult learners are more satisfied with learning if it applies to their everyday life and if it is practical and current (Givens-King, Sebastian, Stanhope, Hickman, 1997:32). In addition, working in a problem-based manner with various case studies also enabled nurses to extend and improve their knowledge base (in particular regarding disability and beginning communication skills), to remain contemporary in their field and to provide appropriate care for the unique problems they might face in their work (Jacobs, 1997:134). As it was expected of nurses to work independently after the training and to apply the principles to the various CSDs and their caregivers in their caseloads, the value of this approach is evident.

Other adult learning principles such as interactive workshops with activities that encourage a variety of forms of expression were also used. Activities such as role-play and observation elicited rich personal stories and concerns that, through facilitation, led to the development of a clear set of principles in completing case studies (Krogh \& Lindsay, 1999:231). This technique was also helpful in developing problem-solving skills required to address anticipated or unexpected dilemmas. Although workshops, in order to reduce fatigue, never exceeded 60 minutes they were long enough to ensure that the nurses could master and practise the skills taught during the particular session. After completion of the training all nurses received a certificate of attendance, leading to a feeling of achievement and general pride. An outline of the training is provided in Appendix I.

\section{Results}

Level 1: Cross-training of basic patient care skills

This level refers to the medical handling of individuals through completing specific nursing tasks. Since it was not the focus of the training, this aspect will not be described further.

Level 2: Cross-training of professional non-clinical skills The nursing roles related to disability at this level include awareness raising, providing information, referral, feedback and follow-up as discussed in the introduction. Due 


\section{Table 5 Nurses' self-evaluation of nursing skills, specific to working with CSDs and their caregivers, during the various research phases $(n=3 \times 20=60)$}

\begin{tabular}{|c|c|c|c|c|}
\hline No & Description & $\begin{array}{l}\text { Pre-training } \\
\left(O_{1}\right)\end{array}$ & $\begin{array}{l}\text { Post-training } \\
\left(\mathrm{O}_{2}\right)\end{array}$ & $\begin{array}{l}\text { Post-withdrawal } \\
\left(\mathrm{O}_{5}\right)\end{array}$ \\
\hline 1 & $\begin{array}{l}\text { Using different unaided communication means } \\
\text { (e.g. facial expressions, head-nodding and } \\
\text { manual signs) }\end{array}$ & 3 & 2 & 1 \\
\hline 2 & $\begin{array}{l}\text { Using different aided communication means } \\
\text { (e.g. real objects and photos). }\end{array}$ & - & 3 & 2 \\
\hline 3 & Facilitating a positive attitude by giving advice & 18 & 7 & 11 \\
\hline 4 & Demonstrating communication functions & - & 4 & 2 \\
\hline 5 & Providing communication opportunities & - & 4 & 5 \\
\hline 6 & $\begin{array}{l}\text { Social integration by increasing communication } \\
\text { partners and using play }\end{array}$ & 2 & 2 & 4 \\
\hline 7 & $\begin{array}{l}\text { Good communication and listening skills of the } \\
\text { nurse }\end{array}$ & 13 & 11 & 7 \\
\hline \multirow[t]{9}{*}{8} & Service delivery: & & & \\
\hline & - $\quad$ Case history and interviewing & 6 & 4 & 8 \\
\hline & - Identification and screening & 4 & 6 & 5 \\
\hline & - $\quad$ Referral & 3 & - & 1 \\
\hline & - $\quad$ Teaching CSDs & 7 & - & 1 \\
\hline & - $\quad$ Teaching feeding skills & - & 1 & - \\
\hline & $\begin{array}{l}\text { - Teaching caregivers to communicate with } \\
\text { CSD }\end{array}$ & - & 14 & 12 \\
\hline & - Health talk about hygiene & 3 & 1 & - \\
\hline & - Information on disability grant & & - & 1 \\
\hline \multirow[t]{2}{*}{9} & Professional secrecy & 1 & 1 & - \\
\hline & TOTAL & 60 & 60 & 60 \\
\hline
\end{tabular}

Please note that each of the 20 participants were requested to provide 3 answers, hence the total of 60 items.

to the inter-relatedness of these tasks, they are described in a joint manner.

Results for this discussion were obtained from response form II, section E. The three open-ended questions dealt with a general self-evaluation of their skills as nurses; with those skills that positively impacted on the treatment of CSDs and their caregivers, and finally, with skills that they would like to improve in order to enhance their service delivery to CSDs. Combined frequencies for each of these questions were recorded for the different periods, and an item analysis was done. Table 4 depicts the nurses' selfevaluation of their general nursing skills during the three phases.

Table 4 shows that nurses became more aware of the impor- tance of showing caregivers how to communicate with their CSDs (item 10). This awareness was maintained during the post-training and post-withdrawal phases. In addition, in the post-training phase they became aware of the importance of school placement and the provision of follow-up services. The greatest decline in scores during the study was noted regarding the counselling of caregivers to accept their CSDs and to adopt positive attitudes. This decline may be due to the fact that, post-training, nurses had a concrete way of encouraging such acceptance (e.g. using the BCIP as opposed to the traditional counselling methods of talking and discussing). Some aspects received high scores throughout, such as general communication and listening skills, providing correct medical treatment and education through health talks. Referrals remained fairly 


\section{Table 6 Nurses' self-evaluation of skills, specific to working with CSDs and their caregivers, that they would like to improve/receive training in; during the various research phases $(n=3 \times 20=60)$}

\begin{tabular}{|c|c|c|c|c|}
\hline No & Description & $\begin{array}{l}\text { Pre-training } \\
\left(\mathrm{O}_{1}\right)\end{array}$ & $\begin{array}{l}\text { Post-training } \\
\left(\mathrm{O}_{2}\right)\end{array}$ & $\begin{array}{l}\text { Post-withdrawal } \\
\left(\mathrm{O}_{s}\right)\end{array}$ \\
\hline 1 & More information on communication means & 4 & 7 & 13 \\
\hline 2 & Knowing more about communication functions & - & 4 & 2 \\
\hline 3 & $\begin{array}{l}\text { Creating communication opportunities by using } \\
\text { communication temptations }\end{array}$ & - & 5 & - \\
\hline 4 & $\begin{array}{l}\text { Knowing more about multi-disciplinary teams, } \\
\text { each member's role and the referral route }\end{array}$ & 3 & 4 & 4 \\
\hline \multirow[t]{2}{*}{8} & $\begin{array}{l}\text { Service delivery: } \\
\text { - } \quad \text { Screening and measuring progress } \\
\text { - } \quad \text { Caregiver and sibling training } \\
\text { - } \quad \text { Providing primary health care and nursing } \\
\text { - } \quad \text { exercises } \\
\text { - } \quad \text { Inn nursing skills } \\
\text { - } \quad \text { Cating with them } \\
\text { - } \quad \text { fisaborility types } \\
\text { Facilitating independence by functional } \\
\text { - } \quad \text { Teachills } \\
\text { CSDs by families to communicate with } \\
\text { - } \quad \text { Know about schools for CSDs } \\
\text { How to form support groups }\end{array}$ & $\begin{array}{l}- \\
18 \\
3 \\
10 \\
4 \\
13 \\
3 \\
- \\
- \\
-\end{array}$ & $\begin{array}{l}5 \\
4 \\
2 \\
1 \\
2 \\
4 \\
- \\
2 \\
16 \\
3 \\
1\end{array}$ & $\begin{array}{l}4 \\
2 \\
3 \\
3 \\
- \\
3 \\
- \\
3 \\
9 \\
3 \\
1\end{array}$ \\
\hline & TOTAL & 60 & 60 & 60 \\
\hline
\end{tabular}

Please note that each of the 20 participants were requested to provide 3 answers, hence the total of 60 items.

consistent over the three phases.

Secondly, nurses were asked to reflect on their skills that were particularly good when working with CSDs and their caregivers. The results are shown in Table 5.

Table 5 shows that, post-training, nurses were aware of the specific skills that were required when working with CSDs and their caregivers. For example, the highest score was obtained for "teaching caregivers to communicate with $C S D$ s", and this high score was maintained during the postwithdrawal phase. The other skills that were mentioned were specific in nature, for example: "using real objects to communicate", "demonstrating communication means and functions" and "providing communication opportunities". As noted in Table 4, skills mentioned pre-training were vague and general, such as "teaching CSDs" and "facilitate a positive attitude by giving advice". These frequencies declined during post-training as attention became focused on specific aspects, such as "providing communication opportunities", "using aided communication" and "demonstrating communication functions". During the postwithdrawal phase, however, the frequencies for the general aspects increased again, but not to the pre-training level.

Results pertaining to the question about skills that the nurses would have liked to improve and/or receive training in, are shown in Table 6.

Table 6 yields some interesting results. Pre-training, eighteen, thirteen and ten nurses respectively required more training in "training caregivers and siblings", "interviewing caregivers and communicating with them" and "basic training of CSDs". It is clear that the BCIP training programme addressed these issues, because a noticeable posttraining decline was observed for these three aspects. It is 


\begin{tabular}{|c|c|c|c|c|}
\hline No & Advice & $\begin{array}{l}\text { Pre-training } \\
\left(O_{1}\right)\end{array}$ & $\begin{array}{l}\text { Post-training } \\
\left(\mathrm{O}_{2}\right)\end{array}$ & $\begin{array}{l}\text { Post-Withdrawal } \\
\left(\mathrm{O}_{5}\right)\end{array}$ \\
\hline 1 & $\begin{array}{l}\text { Referral (hospital, therapists, social } \\
\text { worker, genetic counselling) }\end{array}$ & 19 & 1 & 2 \\
\hline 2 & Refer to special school & 7 & 3 & 2 \\
\hline 3 & Refer to mainstream school/crèche & 1 & 5 & 9 \\
\hline 4 & Provide medical treatment & 2 & 1 & 1 \\
\hline 5 & Counsel caregivers on acceptance & 14 & 4 & 6 \\
\hline 6 & $\begin{array}{l}\text { Discuss basic communication skills } \\
\text { (e.g. talk slowly) }\end{array}$ & 10 & 5 & 10 \\
\hline 7 & Expand on communication means & - & 28 & 15 \\
\hline 8 & Stimulate communication function & - & 16 & 9 \\
\hline 9 & $\begin{array}{l}\text { Use all possible communication } \\
\text { opportunities (including toys, etc.) }\end{array}$ & 1 & 3 & 6 \\
\hline 10 & Employ communication temptations & - & 12 & 2 \\
\hline 11 & $\begin{array}{l}\text { Increase social interaction, e.g. get } \\
\text { other children to come and play }\end{array}$ & 11 & 11 & 27 \\
\hline 12 & $\begin{array}{l}\text { Employ helper so that mother has more } \\
\text { time available }\end{array}$ & 2 & 3 & - \\
\hline 13 & Increase independence & - & 4 & 1 \\
\hline & TOTAL & 67 & 96 & 90 \\
\hline
\end{tabular}

Please note that some scores are higher than 20 . This is due to the fact that some aspects were grouped together, e.g. No. 7 included manual signs, EasyTalk, objects, etc.

also interesting to note that "categorising CSDs according to disability types" was no longer an issue, post-training. This is possibly due to the fact that the social model for disability was used (in accordance with the World Health Organization's classification system), where the emphasis is placed on participation rather than disability types (WHO, 2001:2). Post-training, nurses identified a whole new set of needs, with "teaching families to communicate with CSDs by using demonstrations" as the most pressing. This could possibly be attributed to the emphasis placed on social inclusion during the training. The other training needs revolved around the specific issues addressed during training; for example, expanding communication means and functions and creating communication temptations. During the post-withdrawal phase the highest reported frequency was for "using different communication means". This might possibly be because nurses were already successfully using some manual signs (gestures for words like "more", "want", "give", etc.), and wanted to expand their current vocabularies.

Level 3: Cross-training of administrative skills

At this level, prevention is the nursing role that relates to disability. The primary focus of the BCIP training was not the primary prevention of disability, but rather on secondary prevention, which is aimed at early identification and thus early referral for further assessment and treatment (Clark, 1996:450). This implies that the primary health care nurse adopts the role of early detector and referral source, by directing caregivers to other possible resources. Examples of such resources are the social worker (for information regarding disability grants), genetic counselling (for family planning), and occupational therapy (for seating and mobility). In addition, secondary prevention highlights the primary health care nurses role as information sources and role models. The nurses model appropriate behaviours to families, while providing them with the relevant information to enable them to make appropriate and knowledge- 
Table 8 Friedman test of knowledge and skills

\begin{tabular}{|l|l|l|l|l|l|}
\hline Aspect & \multicolumn{5}{|l|}{ KNOWLFIDGE } \\
\hline Research period & $\begin{array}{l}\text { Pre-training } \\
\left(\mathbf{O}_{1}\right)\end{array}$ & $\begin{array}{l}\text { Post-training } \\
\left(\mathbf{O}_{2}\right)\end{array}$ & $\begin{array}{l}\text { Follow-up } \\
\left(\mathbf{O}_{3}\right)\end{array}$ & $\begin{array}{l}\text { Follow-up } \\
\left(\mathbf{O}_{4}\right)\end{array}$ & $\begin{array}{l}\text { Post-Withdrawal } \\
\left(\mathbf{O}_{5}\right)\end{array}$ \\
\hline Mean & 15.90 & 29.60 & 30.95 & 32.95 & 33.05 \\
\hline Summary of results & \multicolumn{5}{|l|}{} \\
\hline Aspect & SKILLS & 58.65 & 62.15 & 70.80 & 70.95 \\
\hline Means & 32.80 & 6 & \\
\hline Summary of results & &
\end{tabular}

Means that do not differ statistically significantly from each other, are underlined.

able decisions about their children's rehabilitation (Roberts, Rule \& Innocenti, 1998:69). The type of advice provided to caregivers following a specific case study was obtained from response form 1 , section $C$. Results are shown in table 7.

Table 7 shows that nurses became more aware of different kinds of advice that could be given, as seen in their total scores. Pre-training advice tended to be general (e.g. "counsel caregivers on acceptance"). Post-training and postwithdrawal, the advice given tended to become more specific in nature (e.g. "increasing communication means" and "increasing social interaction"). Generally, nurses also tended to become more aware of the importance of referral to a mainstream school (i.e. referral to special schools decreased). The decline in "referral" over the various research phases was also interesting. This could possibly be due to the fact that nurses became more empowered and confident in assisting CSDs and their caregivers.

Level 4: Cross-training of clinical disciplines

At this level, the nursing roles that relate to disability concerns early identification and screening and planning services. Simply locating and identifying CSDs is not enough; services aimed at minimising the effects of a disability should also be investigated. The purpose of identification is thus intervention (Wilkey \& Gardner, 1999:303). The first aspect of identification and service planning entailed making nurses more aware of the available services and how they could assist caregivers to access these services, and of the importance and role of complete case histories and the provision of specific information. Results related to this aspect are discussed in tables 4 to 7 .

Once the disability has been identified, service provision should commence. CSDs and their families often live in remote rural areas, resulting in primary health care nurses being the only professionals available who are able to provide comprehensive, holistic services "on the spot"(Lequerica, 1997:287). In order to achieve this ideal, professional training should be expanded so that primary health care nurses are able to provide services, albeit limited, to the caregivers of CSDs. This is the nursing role for which primary health care nurses required the most input, and consequently, the emphasis of the BCIP training fell on the provision of knowledge, which was intertwined with skills development. As expressed so aptly by Bruner, "It matters not what we have learned. What we can do with what we have learned; this is the issue..." (cited in Brewer, 1985:3).

Results pertaining to applied knowledge were recorded on response form $\mathrm{I}$, section $\mathrm{B}$. A Friedman test was employed to determine whether the change in applied knowledge was statistically significant over time. A r-value of 0.0001 was noted, implying a statistically significant difference. A summary of these results is shown in Table 8 . The pair wise comparisons showed a statistically significant increase in global applied knowledge at the $1 \%$ confidence level, between the pre-training score $\left(\mathrm{O}_{1}\right)$ and all the following scores, namely the post-training scores $\left(\mathrm{O}_{2}\right)$, the two-week follow-up scores $\left(\mathrm{O}_{3}\right)$, the six-week follow-up scores $\left(\mathrm{O}_{4}\right)$, and the post-withdrawal scores $\left(\mathrm{O}_{5}\right)$. No differences were noted between $\mathrm{O}_{2}, \mathrm{O}_{3}, \mathrm{O}_{4}$ and $\mathrm{O}_{5}$.

To yield data regarding their skills, nurses were asked to demonstrate service delivery in a number of different comparable cases. These demonstrations were video-recorded and documented on response form I, section $\mathrm{D}$. Two independent raters rated the results according to a number of different variables. A $96 \%$ inter-rater reliability was noted throughout (Bornman, 2001:5-3). A Friedman test was employed to determine whether the change in skills was statistically significant over time. A r-value of 0.0001 was noted, implying a statistical significant difference. A summary of these results is shown in Table 8 . It indicates a statistical significant increase of combined skills at the $1 \%$ confidence level between the pre-training scores $\left(\mathrm{O}_{1}\right)$ and all the following scores, namely the post-training scores $\left(\mathrm{O}_{2}\right)$, the two-week follow-up scores $\left(\mathrm{O}_{3}\right)$, and the post-withdrawal scores $\left(\mathrm{O}_{5}\right)$. Results also indicated a statistically significant increase at the $1 \%$ confidence level between the post- 
training $\left(\mathrm{O}_{2}\right)$ and the six-week follow-up scores $\left(\mathrm{O}_{4}\right)$, and between the post-training $\left(\mathrm{O}_{2}\right)$ and the post-withdrawal scores $\left(\mathrm{O}_{\mathrm{s}}\right)$. This implies that skills increased significantly in statistical terms during the follow-up periods, compared to pre-training and post-training. This emphasises the importance of follow-ups in skills development.

\section{Conclusion and}

\section{recommendations for further research}

This article aimed to provide a theoretical framework for understanding the pivotal role of primary health care nurses in providing services to CSDs and their caregivers. Multiskilling, an in-service training strategy through which professionals expand their knowledge and skills, was explored. Finally, research results following a particular multi-skilling training programme, viz. BCIP training, were analysed according to the various nursing roles of primary health care nurses while working with CSDs and their caregivers. From this analysis it became clear that the training had a significant impact on primary health care nurses' acquisition of knowledge and skills in the field of severe disability.

Although this article discusses the value of multi-skilling, it also points out certain gaps in the existing body of knowledge. Recommendations for further research are provided. As discussed, a comprehensive approach to PHC aims at equipping personnel (primary health care nurses, in this research) with many different skills. This multi-skilling could lead to nurses feeling insecure about their primary roles and responsibilities, which could greatly impact on their job satisfaction and motivation. The relationships between multi-skilling and job satisfaction, between multi-skilling and overburdening, and between multi-skilling and motivation to work with CSDs and their caregivers should be further investigated. Conducting a follow-up visit one year post-training, to determine the long-term retention of knowledge and skills, would also provide valuable insights into the training methodology that was used.

\section{References}

ALANT, E 1998: Augmentative and Alternative Communication: The role of community nurses in the rehabilitation of people with severe disabilities. Curationis. 21(2), 17-21.

AMERICAN ASSOCIAION OF COLLEGES OF NURSING (AACN) 1996: Position statement: Interdisciplinary education and practice. Journal of Professional Nursing. 1292), 119-123.

\section{AMERICAN SPEEACH AND HEARING ASSOCIATION} (ASHA) 1996: Technical report of the ad hoc committee on multi-skilling. Supplement No 16 to ASHA. 38(2), 53-61.

BORNMAN, J 2001: The Development of a Primary Level Communication Protocol for Children with Severe Disabilities. Pretoria: University of Pretoria (PhD Dissertation).
BORNMAN, J \& ALANT, E 2002: Community nurses' perceptions of an exposure to children with severe disabilities and their primary caregivers. Health SA Gesondheid. 7(3), 32-55.

BORNMAN, J \& ALANT, E 1997: A school-based demographic survey of non-speaking children's communication and functional literacy skills. South African Journal of Education. 17(1), 15-20.

BREWER, IM 1985: Learning more and teaching less. A decade of innovation in self-instruction and small group learning. Surrey: SRHE \& NFER-NELSON.

BRINK, HI 1999: Fundamentals of research methodology for health care professionals ( $2^{\text {nd }}$ ed.). Cape Town: Juta and Co Ltd.

BORTZ, MA; JARDINE, CA \& TSHULE, M 1996: Training to meet the needs of the communicatively impaired population of South Africa: A project of the University of the Witwatersrand. European Journal of Disorders of Communication. 31(1), 465-476.

BURD, L; HAMMES, K; BORNHOEFT, DM \& FISHER, W 1988: A North Dakota prevalence study of nonverbal school-age children. Language Speech and Hearing Services in Schools. 19(4), 371-383.

CLARK, MJ 1996: Nursing in the community ( $2^{\text {nd }}$ ed.). Stamford: Appleton \& Lange.

DEPARTMENT OF HEALTH 1999: The primary health care package for South Africa -A set of norms and standards. Pretoria: Department of Health.

GEYER, N 1997: The national qualifications framework (NQF) - How will nursing education fit in? Health SA Gesondheid 2(1), 10-16.

GIVENS-KING,M;SEBASTIAN,JG; STANHOPE,MK\& HICKMAN, MJ 1997: Using problem-based learning to prepare advanced practice community health nurses for the $21^{\text {st }}$ century. Family Community Health. 20(1), 29-39.

GRIFFITH, HM 1994: Nursing's role in the delivery of clinical preventative services. Journal of Professional Nursing. 10(2): 69 .

HITCHCOCK, JE 1999: Frameworks for assessing families. (In: JE Hitchcock, PE Schubert, \& SA Thomas (Eds.): Community health nursing: Caring in action. (pp. 407-437). Albany: Delmar Publishers.

HUMPHRY, R 1995: Families who live in poverty: Meeting the challenge of family-centred services. The American Journal of Occupational Therapy. 49(7), 687-693.

HURST, K 1999: Educational implications of multi-skilled health carers. Medical Teacher. 21(2), 170-174. 
JACOBS, T 1997: Developing integrated education programmes for occupational therapy: The problem of subject streams in a problem-based course. British Journal of Occupational Therapy. 60(3). 134-138.

KROGH, KS \& LINDSAY, PH 1999: Including people with disabilities in research: Implications for the field of augmentative and alternative communication. Augmentative and Alternative Communication. 15(4): 222-233.

LERNER, H \& ROSS, L 1991: Primary health care nurses and high-risk infants: The current role of Public Law 99457. Infants and Young Children. 4(1): 46-53.

LEQUERICA, M 1997: Towards a one-stop model of service for low-income preschoolers: insights from clinical practice and research. Infant-Toddler Intervention. The Transdisciplinary Journal. 7(4): 285-300.

MATAS,JA; MATHY-LAIKKO,P; BEUKELMAN,DR \& LEGRESLEY, K 1985: Identifying the non-speaking population: A demographic study. Augmentative and Alternative Communication. 1(1): 17-31.

MCMILLAN,JH \& SCHUMACHER,S 2001: Research in Education. A conceptual introduction $\left(5^{\text {th }}\right.$ ed.). New York: Longman.

MOODLEY, L; LOUW, B \& HUGO, SR 2000: Early identification of at-risk infants and toddlers: A transdisciplinary model of service delivery. The South African Journal of Communication Disorders. 47: 25-39.

NATIONAL DEPARTMENT OF EDUCATION 2002: The draft guidelines for the implementation of inclusive education. Pretoria: Department of Education.

PIETRANTON, AA \& LYNCH, C 1995: Multi-skilling. A Renaissance or a Dark Age? ASHA. 37(6): 37-40.

ROBERTS, R.N., RULE, S. \& INNOCENTI, MS. 1998: Strengthening the Family-professional Partnership in Services for Young Children. Baltimore: Paul H. Brookes Publishing Company.

SOUTH AFRICAN NURSING COUNCIL 1984: R2598, as amended. Regulations relating to the scope of practice of persons who are registered or enrolled under the Nursing Act, 1978. Pretoria: Government Printer.

SOUTH AFRICAN NURSING COUNCIL. 1985: R425, as amended. Regulations relating to the approval of and the minimum requirements for the education and training of a nurse (general, psychiatric and community) and midwife leading to registration. Pretoria: Government Printer.

THOMAS, SA 1999: Historical development of community health nursing. (In: JE Hitchcock, PE Schubert \& SA Thomas (Eds.): Community health nursing: Caring in action pp. 17-38). Albany: Delmar Publishers.
WILKEY, SF \& GARDNER, SS 1999: The varied roles of

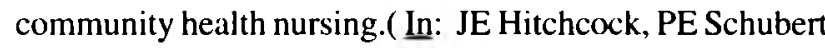
\& SA Thomas (Eds.): Community health nursing: Caring in action. pp. 301-334). Albany: Delmar Publishers.

WORLD HEALTH ORGANIZATION (WHO) 2001: ICIDH-2. International Classification of Functioning and Disability. Final draft. Full version. Geneva: World Health Organisation. 


\begin{tabular}{|c|c|c|c|c|}
\hline Day & Aims & $\begin{array}{l}\text { Competencies (Learning } \\
\text { outcomes) }\end{array}$ & Theoretical discussion & Practical session \\
\hline 1 & $\begin{array}{l}\text { 1. To contextualise the } \\
\text { training within Primary } \\
\text { Health Care (PHC) and the } \\
\text { human rights of CSDs } \\
\text { 2. To highlight the impor- } \\
\text { tance of communication } \\
\text { 3. To explain the concept } \\
\text { "severe disability" } \\
\text { 4. To discuss "multi- } \\
\text { skilling" and highlight the } \\
\text { nurse's role in training be- } \\
\text { ginning communication } \\
\text { skills }\end{array}$ & $\begin{array}{l}\text { Nurses will demonstrate } \\
\text { their knowledge about the } \\
\text { human rights of CSDs, the } \\
\text { importance of communica- } \\
\text { tion for CSDs, the concepts } \\
\text { "severe disability" and } \\
\text { "multi-skilling" and their } \\
\text { role in training beginning } \\
\text { communication skills. }\end{array}$ & $\begin{array}{l}\text { The importance of the BCIP } \\
\text { training in terms of PHC, } \\
\text { the human rights of CSDs } \\
\text { and the importance of com- } \\
\text { munication were dis- } \\
\text { cussed. The devastating } \\
\text { effect of non-speech was } \\
\text { demonstrated by means of } \\
\text { video clips. Next the con- } \\
\text { cept "severe disability" } \\
\text { and the difficulties of work- } \\
\text { ing with CSDs as well as } \\
\text { the WHO's classification } \\
\text { system that focuses on } \\
\text { participation were dis- } \\
\text { cussed. Finally disability } \\
\text { was integrated into nurs- } \\
\text { ing practice by highlight- } \\
\text { ing "multi-skilling". }\end{array}$ & $\begin{array}{l}\text { Nurses divided into } \\
\text { small groups of three } \\
\text { and discussed how } \\
\text { they would plan a dis- } \\
\text { ability campaign to } \\
\text { lessen the impact of dis- } \\
\text { ability in their health } \\
\text { district. Each group ad- } \\
\text { dressed one of the fol- } \\
\text { lowing elements: } \\
\text { - Awareness } \\
\text { - Information } \\
\text { - Referral } \\
\text { - Feedback \& follow- } \\
\text { up } \\
\text { - Prevention } \\
\text { - Identification } \\
\text { \& screening } \\
\text { - Planning services }\end{array}$ \\
\hline 2 & $\begin{array}{l}\text { 1. To describe the four ma- } \\
\text { jor areas that impact on } \\
\text { communication } \\
\text { 2. To discuss the develop- } \\
\text { ment of communication } \\
\text { functions through the pro- } \\
\text { vision of deliberate commu- } \\
\text { nication opportunities } \\
\text { 3. To facilitate the develop- } \\
\text { ment of skills related to be- } \\
\text { ginning communication } \\
\text { functions and the creation } \\
\text { of communication opportu- } \\
\text { nities during activities of } \\
\text { daily living. }\end{array}$ & $\begin{array}{l}\text { Nurses will demonstrate } \\
\text { their knowledge about dif- } \\
\text { ferent beginning communi- } \\
\text { cation functions and delib- } \\
\text { erate communication oppor- } \\
\text { tunities. } \\
\text { Nurses will demonstrate the } \\
\text { skill to deliberately create } \\
\text { communication opportuni- } \\
\text { ties through the use of com- } \\
\text { munication temptations }\end{array}$ & $\begin{array}{l}\text { Four main communication } \\
\text { domains viz. functions, } \\
\text { means, content and part- } \\
\text { ners were discussed. The } \\
\text { focus was then placed on } \\
\text { beginning communication } \\
\text { functions (choice-making, } \\
\text { labelling, requesting help, } \\
\text { requesting more, drawing } \\
\text { attention, protesting, "yes' } \\
\text { concept and showing hu- } \\
\text { mour \& surprise). Specific } \\
\text { strategies to elicit these } \\
\text { functions ("communica- } \\
\text { tion temptations") were } \\
\text { then demonstrated. This } \\
\text { included providing } \\
\text { choices, making desired } \\
\text { items inaccessible, select- } \\
\text { ing materials that require } \\
\text { assistance, providing small } \\
\text { portions or brief turns, de- } \\
\text { liberately withholding at- } \\
\text { tention, offering non-pre- } \\
\text { ferred items and violating } \\
\text { expectations. Finally a } 5- \\
\text { point plan for answering } \\
\text { case studies was given and } \\
\text { discussed. }\end{array}$ & $\begin{array}{l}\text { After the discussion } \\
\text { and demonstration of a } \\
\text { particular communica- } \\
\text { tion function and temp- } \\
\text { tation, participants were } \\
\text { asked to practise the } \\
\text { skill using the BCIP. Fi- } \\
\text { nally nurses were di- } \\
\text { vided into small groups } \\
\text { and each group had to } \\
\text { explain how they would } \\
\text { conduct service deliv- } \\
\text { ery and then demon- } \\
\text { strate their newly ac- } \\
\text { quired skill. All case } \\
\text { studies differed to en- } \\
\text { sure that there was no } \\
\text { duplication of facts and } \\
\text { that all the different } \\
\text { functions that were } \\
\text { taught could be demon- } \\
\text { strated. An example of a } \\
\text { case study is: "Simon is } \\
\text { a four year old spastic } \\
\text { boy. He cannot sit un- } \\
\text { supported and al- } \\
\text { though he cannot use } \\
\text { his arms he cannot } \\
\text { point. How will you } \\
\text { teach him to point?" }\end{array}$ \\
\hline
\end{tabular}




\begin{tabular}{|c|c|c|c|c|}
\hline Day & Aims & $\begin{array}{l}\text { Competencies (Learning } \\
\text { outcomes) }\end{array}$ & Theoretical discussion & Practical session \\
\hline 3 & $\begin{array}{l}\text { 1. To revisit the four major } \\
\text { areas that impact on com- } \\
\text { munication } \\
\text { 2. To discuss different com- } \\
\text { munication means (aided } \\
\text { and unaided) } \\
\text { 3. To facilitate the develop- } \\
\text { ment of skills related to the } \\
\text { implementation of aided } \\
\text { and unaided communica- } \\
\text { tion strategies }\end{array}$ & $\begin{array}{l}\text { Nurses will demonstrate } \\
\text { knowledge of the various } \\
\text { aided and unaided commu- } \\
\text { nication means included in } \\
\text { the BCIP }\end{array}$ & $\begin{array}{l}\text { Nurses will demonstrate } \\
\text { skill in implementing the } \\
\text { various aided and unaided } \\
\text { strategies in the BCIP } \\
\text { The four main communica- } \\
\text { tion domains were dis- } \\
\text { cussed, highlighting } \\
\text { means. This was followed } \\
\text { by a discussion of the con- } \\
\text { cept "Augmentative and } \\
\text { Alternative Communica- } \\
\text { tion" after which the aided } \\
\text { and unaided strategies in- } \\
\text { cluded in the BCIP were } \\
\text { discussed and demon- } \\
\text { strated. The unaided strat- } \\
\text { egies included gestures } \\
\text { (e.g. pointing, yes/no } \\
\text { headshake, facial expres- } \\
\text { sions, miming and ges- } \\
\text { tures) sign language } \\
\text { (SASL) and natural ges- } \\
\text { tures. The aided strategies } \\
\text { include real objects, colour } \\
\text { photographs, PCS and a } 4- \\
\text { option digital speaker. Ad- } \\
\text { vantages and disadvan- } \\
\text { tages of each were high- } \\
\text { lighted. }\end{array}$ & $\begin{array}{l}\text { After a discus- } \\
\text { sion and demonstration } \\
\text { of the various aided and } \\
\text { unaided communication } \\
\text { strategies included in } \\
\text { the BCIP, nurses had } \\
\text { the opportunity to prac- } \\
\text { tise these skills. All } \\
\text { means were first prac- } \\
\text { tised in isolation (e.g. } \\
\text { "Make the gesture for } \\
\text { "open") after which } \\
\text { they had to incorporate } \\
\text { it with their skills of the } \\
\text { previous day (e.g. use a } \\
\text { gesture to provide a } \\
\text { choice). This was done } \\
\text { is small groups where } \\
\text { the roles constantly } \\
\text { changed between a } \\
\text { nurse acting as the CSD, } \\
\text { a caregiver and a nurse. } \\
\text { Skills were then applied } \\
\text { to a specific case. } \\
\end{array}$ \\
\hline 4 & $\begin{array}{l}\text { 1. To revisit the four major } \\
\text { areas that impact on com- } \\
\text { munication } \\
\text { 2. To discuss different com- } \\
\text { munication contexts / envi- } \\
\text { ronments } \\
\text { 3. To discuss the inclusion } \\
\text { of different partners } \\
\text { 4. To highlight general in- } \\
\text { tervention principles }\end{array}$ & $\begin{array}{l}\text { Nurses will demonstrate } \\
\text { knowledge of the impor- } \\
\text { tance of including different } \\
\text { communication partners and } \\
\text { environments in the inter- } \\
\text { vention process as well as } \\
\text { the general intervention prin- } \\
\text { ciples } \\
\text { Nurses will demonstrate } \\
\text { skill in implementing the } \\
\text { BCIP by including interven- } \\
\text { tion principles, contexts and } \\
\text { partners }\end{array}$ & $\begin{array}{l}\text { The four major communi- } \\
\text { cation domains covered by } \\
\text { the BCIP were revisited, } \\
\text { highlighting the impor- } \\
\text { tance of the communica- } \\
\text { tion context (environment) } \\
\text { and partners. The impor- } \\
\text { tance of these two aspects } \\
\text { was highlighted by discus- } \\
\text { sions, demonstrations and } \\
\text { video examples. All infor- } \\
\text { mation was related back to } \\
\text { the BCIP by focusing on } \\
\text { the three contexts covered, } \\
\text { namely bath time, mealtime } \\
\text { and dressing/undressing. } \\
\text { To conclude a few general } \\
\text { intervention principles that } \\
\text { should be adhered to at all } \\
\text { times, e.g. the importance } \\
\text { of maintaining a "give- } \\
\text { and-take balance" were } \\
\text { addressed. }\end{array}$ & $\begin{array}{l}\text { Small groups were } \\
\text { formed where everyone } \\
\text { had an opportunity to } \\
\text { take on different roles } \\
\text { while practising the im- } \\
\text { plementation of the dif- } \\
\text { ferent contexts pro- } \\
\text { vided by the BCIP. Par- } \\
\text { ticipants were asked to } \\
\text { specifically address the } \\
\text { issues of involving dif- } \\
\text { ferent communication } \\
\text { partners. General inter- } \\
\text { vention principles were } \\
\text { integrated into these } \\
\text { role-play sessions. Fi- } \\
\text { nally nurses role-played } \\
\text { their recommendations } \\
\text { with a specific case, e.g. } \\
\text { "Nomsa is 7-years old } \\
\text { and spends her days } \\
\text { with her } 80-y e a r \text { old } \\
\text { grandmother who } \\
\text { doesn't want her to at- } \\
\text { tend school. Her only } \\
\text { toy is a broom that she } \\
\text { pushes around aim- } \\
\text { lessly" }\end{array}$ \\
\hline
\end{tabular}




\begin{tabular}{|c|c|c|c|c|}
\hline Day & Aims & $\begin{array}{l}\text { Competencies (Learning } \\
\text { outcomes) }\end{array}$ & Theoretical discussion & Practical session \\
\hline 5 & $\begin{array}{l}\text { 1. To describe the impor- } \\
\text { tance of monitoring } \\
\text { progress } \\
\text { 2. To complete a checklist } \\
\text { designed for monitoring } \\
\text { progress } \\
\text { 3. To apply the checklist to } \\
\text { a case study. }\end{array}$ & $\begin{array}{l}\text { Nurses will demonstrate } \\
\text { knowledge regarding the } \\
\text { importance of monitoring } \\
\text { progress. } \\
\text { Nurses will demonstrate } \\
\text { skills in applying the } \\
\text { Progress Checklist to a par- } \\
\text { ticular case study. }\end{array}$ & $\begin{array}{l}\text { The theoretical rationale } \\
\text { for monitoring progress } \\
\text { was discussed. Following } \\
\text { this each item in the } \\
\text { Progress Checklist that } \\
\text { consists of three sections, } \\
\text { namely the child (compris- } \\
\text { ing communication means } \\
\text { and functions), the part- } \\
\text { ners and environment } \\
\text { (comprising information } \\
\text { about the partners and } \\
\text { daily living information } \\
\text { about the child within the } \\
\text { environment) and the } \\
\text { nurse's observation (in } \\
\text { terms of communication } \\
\text { temptations) were dis- } \\
\text { cussed. }\end{array}$ & $\begin{array}{l}\text { Three video cases were } \\
\text { shown and a Progress } \\
\text { Checklist was com- } \\
\text { pleted for each case. } \\
\text { This was done in the } \\
\text { group as a whole. Each } \\
\text { score was then dis- } \\
\text { cussed in order to gain } \\
\text { consensus and to act } \\
\text { as in-service training. } \\
\text { This was followed by } \\
\text { another two more video } \\
\text { cases, which nurses } \\
\text { completed a checklist in } \\
\text { the small groups. } \\
\text { Scores were again dis- } \\
\text { cussed and nurses were } \\
\text { able to objectify their } \\
\text { given scores. High cor- } \\
\text { relation was found after } \\
\text { the } 5^{\text {th }} \text { video case. This } \\
\text { was followed by a case } \\
\text { study discussion simi- } \\
\text { lar to the one discussed } \\
\text { in response form I. }\end{array}$ \\
\hline
\end{tabular}




\begin{tabular}{|c|c|c|}
\hline PERIOD & CASESTUDY DESCRIPTION & DIFFERENCFS \\
\hline $\begin{array}{l}\text { Pre-training } \\
\left(\mathrm{O}_{1}\right)\end{array}$ & $\begin{array}{l}\text { Mrs. Serudu has brought her 5-year-old son, Sibusiso to you } \\
\text { for help. She has noticed that he is developing slower than the } \\
\text { neighbour's boy who is about the same age. Although he can } \\
\text { sit, walk and even run, these skills only developed late. Her } \\
\text { major concern is that Sibusiso is not talking well. He can only } \\
\text { say "Mama" and "Eee" to indicate "yes". He also shows her } \\
\text { his empty plate when he has finished eating and wants her to } \\
\text { clap hands for him. She thinks that he understands more than } \\
\text { what he is able to say. Mrs Serudu has a spaza shop at her } \\
\text { house and she finds it difficult if he interferes when she has } \\
\text { customers. She wants him to greet the customers properly. }\end{array}$ & \\
\hline $\begin{array}{l}\text { Post- } \\
\text { training } \\
\left(\mathrm{O}_{2}\right)\end{array}$ & $\begin{array}{l}\text { Mrs. Kekana has brought her 5-year-old daughter, Karabo to } \\
\text { you for help. She has noticed that Karabo is developing slower } \\
\text { than her 4-year old brother. Although Karabo can sit, walk and } \\
\text { even run, these skills only developed late. Mrs Kekana's major } \\
\text { concern is that Karabo is not talking well. She can only say } \\
\text { "uh" to indicate "yes" and "Mama". When she is thirsty, she } \\
\text { will show her cup. When she finishes any task she wants the } \\
\text { family to clap hands for her. Mrs Kekana thinks that Karabo } \\
\text { understands more than what she is able to say. Mrs Kekana } \\
\text { works from home and does repairs and alterations to clothing. } \\
\text { She finds it difficult when Karabo interferes when she is busy } \\
\text { with a customer. She wants Karabo to be polite and greet the } \\
\text { customers properly. }\end{array}$ & $\begin{array}{l}\text { - Name and surname } \\
\text { - Gender of child } \\
\text { - Person child is compared with } \\
\text { - Examples of single words used. } \\
\text { - Object used for communication } \\
\text { - Care-giver's work description }\end{array}$ \\
\hline $\begin{array}{l}\text { Follow-up } 1 \\
\left(\mathrm{O}_{3}\right)\end{array}$ & $\begin{array}{l}\text { Mrs. Mahlangu has brought her 5-year-old daughter, Maria, to } \\
\text { you for help. She has noticed that Maria is developing slower } \\
\text { than her other 4-year old daughter. Although Maria can sit, } \\
\text { walk and even run, these skills only developed late. Mrs } \\
\text { Mahlangu's major worry is that Maria is not talking well. She } \\
\text { can only make a noise to say "yes" and she says "Mama". } \\
\text { When she is hungry, she will show her spoon. When she fin- } \\
\text { ishes her food she wants the family to clap hands for her. Mrs } \\
\text { Mahlangu thinks that Maria understands more than what she } \\
\text { is able to say. Mrs Mahlangu has a hair salon at her house } \\
\text { where she does hair cutting and plaiting. She finds it difficult } \\
\text { when Maria interferes when she is busy with a customer. She } \\
\text { wants Maria to be polite and greet the customers properly. }\end{array}$ & $\begin{array}{l}\text { - Name and surname } \\
\text { - Gender of child } \\
\text { - Person child is compared with } \\
\text { - Examples of single words used. } \\
\text { - Object used for communication } \\
\text { - Care-giver's work description }\end{array}$ \\
\hline $\begin{array}{l}\text { Follow-up } 2 \\
\left(\mathrm{O}_{4}\right)\end{array}$ & $\begin{array}{l}\text { Mrs. Shibambu has brought her 5-year-old son, Joseph, to you } \\
\text { for help. She has noticed that Joseph is developing slower than } \\
\text { the neighbour's son who is about the same age. Although } \\
\text { Joseph can sit, walk and even run, these skills only developed } \\
\text { at a late stage. Mrs Shibambu's major worry is that Joseph is } \\
\text { not talking well. He can only make an "aaa" sound to say "yes" } \\
\text { and he says "Mama". When he is thirsty, he will show his mug. } \\
\text { When he finishes his food he wants the family to clap hands } \\
\text { for him. Mrs Shibambu thinks that Joseph understands more } \\
\text { than what he is able to say. Mrs Shibambu has a small catering } \\
\text { business at her house where she makes "bunny chow". She } \\
\text { finds it difficult when Joseph interferes when she is busy with } \\
\text { a customer. She wants Joseph to be polite and greet the cus- } \\
\text { tomers properly. }\end{array}$ & $\begin{array}{l}\text { - Name and surname } \\
\text { - Gender of child } \\
\text { - Person child is compared with } \\
\text { - Examples of single words used. } \\
\text { - Object used for communication } \\
\text { - Care-giver's work description }\end{array}$ \\
\hline $\begin{array}{l}\text { Post-With- } \\
\text { drawal } \\
\left(\mathrm{O}_{5}\right)\end{array}$ & $\begin{array}{l}\text { The same case study was used for phases } \mathrm{O}_{1} \text { and } \mathrm{O}_{5} \text { as it was } \\
\text { assumed that nurses would not remember the exact details of } \\
\text { the particular case study after the } 5 \text { months lapse during which } \\
\text { time they were exposed to three other cases. }\end{array}$ & \\
\hline
\end{tabular}

